\title{
Ties that bind, can also strangle: the Brexit threat and the hardships of reforming the EU
}

\author{
Daniela Annette Kroll and Dirk Leuffen \\ Department of Politics \& Public Administration, University of Konstanz, Germany
}

\begin{abstract}
This article links insights from research on European Union (EU) decisionmaking and on differentiated integration to the recent negotiations about the future United Kingdom (UK)-EU relationship. We argue that since a Brexit would overturn well-established statics of EU decision-making, EU member states reacted differently to the British demands. States that feared a weakening of their position after a Brexit were more willing to grant concessions to the UK. This largely applies to most northern member states. In contrast, most other member states appeared more reluctant to meet the British expectations. First, these states hoped to improve their standing inside the EU after a Brexit. Second, reflecting deeper structural tensions, the British demands would have entailed higher prices for these member states. Anticipating heterogeneity between the other member states, and thus the stability enhancing mechanisms of the joint decision trap, the UK downscaled its demands before the European Council of February 2016. In consequence, the negotiations on the terms of Britain's EU membership did not result in a grand overhaul of the EU, but rather in symbolic concessions aimed at pleasing British domestic politics without severely harming other member states' interests.
\end{abstract}

\section{Introduction}

The clear victory of the Conservatives in the British general election in May 2015 put the issue of a British exit from the European Union, a 'Brexit', high on the agenda. Following the agreement reached at the European Council summit in February 2016, Prime Minister (PM) David Cameron has announced to hold an in/out referendum on 23 June 2016. At the same time, Cameron, who has repeatedly underlined having no 'romantic attachment to the European Union and its institutions' (Cameron 2015), henceforth stated that he will 'campaign ... with all [of his] heart and soul' (Prime Minister's Office et al. 2016) for Britain to remain in the European Union (EU). What for an outsider 
might look like a surprising change of mind is justified by Cameron by arguing that the renegotiated terms would give Britain a 'special status' and enable it to profit from 'the best of both worlds' (ibid.). In such a reading, the renegotiation of the membership terms was highly successful.

In this article, we are more sceptical about the negotiation success. We draw on the well-known two-level game literature (Putnam 1988) and explore whether the Brexit threat was actually able to bring about substantive reforms. In a two-level game perspective, a referendum threat should have strengthened the United Kingdom's (UK's) bargaining position vis-àvis the other EU member states. However, the success or causal effect of the strategy depends on two conditions. First, a threat needs to be credible. Indeed, polls show that the British public was almost equally divided between the 'remain' and 'leave' camps; thus, a Brexit was not an entirely unrealistic scenario. Second, the success of the strategy depended upon the potential costs of a non-agreement. How strongly would the other member states value British membership in comparison to the expected costs of a Brexit? If Cameron had pushed the boundaries during the negotiations too far, he would have risked - in game theoretic terms - involuntary defection.

In the following, we will argue that despite the Brexit threat, the UK did not achieve far-reaching policy changes in the negotiations. While some member states seemed to strongly value British membership (Oliver 2016) and to support some of its reform ideas - thus, being more willing to grant concessions to the UK - others were more reluctant (Jensen and Snaith 2016). Being veto players, the reluctant states were able to put the brakes on the negotiations; a typical situation in systems characterized by joint-decision traps (Scharpf 1988; Tsebelis 2002). Furthermore, a more differentiated 'Europe á la carte' advocated by the UK did not emerge from the negotiations. The reason for this is that the UK's bargaining position was weak in contrast to previous rounds of differentiated integration negotiations (cf. Leuffen et al. 2015). In past negotiations, the UK was close to the status quo and able to block changes, and thus had a strong bargaining position. In the negotiations, the UK desired a change from the status quo towards less integration. Given that 'cherry picking' by individual member states is generally not appreciated very much in the EU (cf. Butler et al. 2016; Holzinger and Schimmelfennig 2012; Kroll and Leuffen 2015; Stubb 1996), the other member states were hesitant to provide more generous concessions.

Anticipating these difficulties, the UK has cautiously formulated its reform demands. We argue that by avoiding explicitly stating what it really wanted, the British government aimed at reducing 'audience costs' (cf. Fearon 1994) that would arise from falling short of initial demands. Furthermore, it wanted to avoid involuntary defection on the part of the other EU member states and thereby increase the likelihood of a Brexit. 


\section{Negotiating change in the EU: a rationalist reading}

In their contribution, Jensen and Snaith (2016) find that David Cameron's motivation for the decision to hold a referendum was purely domestic; in particular, these authors argue that the PM aimed at maintaining coherence in his own party. However, PM Cameron might have also chosen to hold a referendum to strengthen his bargaining position vis-à-vis the European partners. The two-level game literature teaches us that domestically 'tied hands' can promote bargaining success at the international level (Evans et al. 1993; Putnam 1988); Schelling (1963: 22) famously speaks of the 'paradox of weakness'. Was this strategy successful in pushing the UK's reform agenda in the EU? We are sceptical, and will outline the reasons in the following.

Simplifying matters, the EU reform negotiations could have resulted in three possible outcomes. In the first scenario, no reforms would have been carried out and the integrationist status quo prevailed. Given that the British government had conditionally linked its approval of membership to reforms, such an outcome would make a Brexit highly likely. PM Cameron declared that 'if we can't reach ... an agreement and if Britain's concerns were to be met with a deaf ear, ... I rule nothing out' (Prime Minister's Office et al. 2015). Before the February 2016 European Council, Cameron again underlined that he would only accept an outcome in which British concerns were sufficiently taken into account. In the second scenario, some minor, more or less cosmetic reforms in the EU would be agreed to. In comparison to scenario one, the face-saving concessions of scenario two should reduce the probability of a Brexit. In the third scenario, the EU would undergo substantive reforms in the direction desired by the British. In such a scenario, the risk of a Brexit would further decrease.

How should the actors rank the different possible outcomes? Clearly, the British government should have preferred scenario three over scenario two over scenario one. The other member states, in principle, should favour keeping the UK in the EU, since a Brexit would impose high costs on the Union. For example, a lack of future harmonization between the EU and the UK as a non-Member State should lead to higher transaction costs, a lower external impact of the Union and, of course, losses 'attached to pursuing integration as a united Europe' (Jensen and Slapin 2012: 784). However, there are reasons for questioning the assumption of all member states being equally affected and, thus, against the Brexit. Simplifying matters, we can distinguish two camps. A first group of UK supporters should have been more willing to grant concessions to the UK, fearing higher costs from a Brexit. In contrast, a camp of sceptics to the British position should have been more reluctant to grant concessions, given that these states might profit from a possible shift of the centre of gravity inside the EU. While the UK supporters should thus prefer the negotiation outcome of minor reforms (scenario two) over major 
reforms (scenario three), and over the status quo (scenario one), the sceptics should rank scenario two over scenarios one and three. This preference constellation made outcome two rather likely; and this had also been anticipated by the British government.

\section{When anticipating resistance: remain vague and adjust your demands!}

The Irish government has been one of the most vocal supporters of the British reform ideas in the EU. Fearing disastrous impacts on bilateral trade relations and the Northern Ireland peace process, Taoiseach (PM) Enda Kenny declared the Brexit to be 'a major strategic risk for Ireland' (Department of the Taoiseach 2015). More generally, northern EU member states largely belonged to the camp of the UK supporters. These states often agree with the UK's outlook on policies (Dobbins et al. 2005; Thomson 2011) and regularly vote in line with the UK in EU decision-making (van Aken 2012). For example, the Netherlands usually share the UK's preferences on trade policy or economic governance, and while the Dutch generally supported British claims for a stronger role of national parliaments in EU decision-making, they still preferred a better application of the subsidiarity principle within the existing treaties instead of a repatriation of EU competences to the national level (Korteweg 2014). Another example of a close ally of Britain is Sweden. Sweden generally sides with the UK when it comes to free trade, a deepened Single Market and a small EU budget; and has very similar outward-oriented and liberal economic visions. However, the Swedish government has been rather sceptical about a 'Europe à la carte' (Brattberg 2014). Germany, too, can be considered as a UK supporter. The German government has repeatedly confirmed its willingness to come to terms with the UK to preserve an EU of 28 member states. Since Germany holds trade preferences similar to those held by the UK, it feared that a Brexit would strengthen the Mediterranean bloc, which is often argued to favour a stronger protectionism in EU external trade (Booth et al. 2015). Yet, while Berlin backed the British demand to restrict EU migrants' access to welfare benefits, it also declared the principles of free movement of persons and non-discrimination of the Single Market to be 'unnegotiable' (Bundeskanzleramt 2015).

In contrast, as argued above, the southern member states should have been less willing to grant concessions to the UK (see Jensen and Snaith 2016; Oliver 2016). In fact, the potential shift of the internal balance towards the South as a consequence of a Brexit has been pointed out by several authors (cf. Traynor 2015; Zuleeg 2014). States with a less liberal outlook might benefit from a Brexit, since one of the most liberal voices would leave the EU. In the words of one Council General Secretariat official: 
[The UK] is part of the overall equilibrium in Europe, historically speaking; ... it is in the overall interest of Europe that the Brits are part of it. If they [left], it would definitely alter the balance. I think Europe would then end up probably a bit less 'free trade', a bit less liberal, a bit more, I would say, dirigiste, a bit less marketoriented. (EU official of the General Secretariat of the Council, Brussels, 5 October 2015)

According to another official of the Council Secretariat, France should not find itself amongst the most fervent UK supporters, since a Brexit might 'shift the weight ... strongly towards France' and 'the Union would become more protectionist' (EU official of the General Secretariat of the Council, Brussels, 29 September 2015).

Anticipating disagreement amongst the other member states and seeing the danger of a gridlock, the UK government waited for months to reveal its goals. After announcing his intention to hold a referendum in his speech at Bloomberg in January 2013, PM Cameron held bilateral talks with all EU partners. Furthermore, the matter was on the agenda of the European Council in June, October and December 2015. We can thus assume that the difficulties of achieving significant concessions were well-known to the UK government. And, indeed, despite repeated promises to clarify its reform agenda, the UK hesitated to present a precise wish list. Even the long-awaited letter to the European Council President finally issued in November 2015 primarily contained well-known statements (Buchsteiner 2015). Anticipating and sensing opposition to far-reaching reforms, the British demands remained imprecise and rather modest. An EU official pointed out to us that

[T]he Brits have not put on the table the terms of reference of what they want. Just very generically; ... they did not say: 'A, B, C, or D, or I will campaign for out.' ... I am sure that at that moment when everyone has stated what they are ready to accept, what they are not ready to accept, at that moment, the Brits will say 'Okay, then what we want is the following.' They will never say something what they want without having the guarantee that the others will ultimately accept. So, then [Cameron] can go to its own constituency and say: 'Look guys, I have asked for this. I got it.' (EU official of the Cabinet of the European Council President, Brussels, 7 October 2015).

The nebulosity of the British demands can thus be considered a negotiation tactic. While the vagueness of the UK proposals were unwelcomed by the EU institutions and some of the other member states (Oliver 2016), we find that if the government had demanded more significant reforms, it would augmented its domestic audience costs. In order to ensure that at least some of its demands would be met, the UK government had to adjust its claims; or following Francis Bacon's famous dictum, 'If the hill will not come to Mahomet, Mahomet will go to the hill.'

The other member states seemed ready to play the game. Before and after European Council President Tusk tabled a draft agreement on 2 February 
2016, PM Cameron again negotiated with the strongest adversaries. Whereas David Cameron hailed the draft deal as substantive progress and being 'good enough' (Zalan 2016), Tusk emphasized that 'there are still challenging negotiations ahead' and '[n]othing is agreed until everything is agreed' (European Council 2016). The Commission joined in dramatizing the situation by arguing that the fundamental core of the EU was touched and key issues were left open for negotiations between the leaders in mid-February 2016 (EU official of the Cabinet of the Commission President, Brussels, 9 March 2016).

\section{Negotiating a compromise agreement}

Important reforms generally require unanimity amongst the EU member states. Given that the member states were divided about granting concessions to the UK, scenario three of major reforms was unlikely to result from the February 2016 summit. By adjusting its demands beforehand, the UK wanted to make sure that the summit would allow an outcome that could be sold as a success at home. In consequence, most achievements, like, for example the exemption of the UK from further political integration, are mainly symbolic. Pleas for better regulation or increased competitiveness reflect commonly shared goals. Where substantive issues were on the negotiation table, typical compromise solutions emerged. Although the status of the eurozone outsiders has been enhanced by requesting a decision to be discussed in the European Council, the British did not achieve a veto of the noneurozone member states on eurozone decisions owing to the fervent French opposition. Similarly, while the role of national parliaments has been strengthened - Council legislative discussions can now be interrupted if 55 per cent of national parliaments issue an opinion within 12 weeks instead of eight - the UK did not secure a 'red card' for national parliaments.

As expected, heterogeneity between the member states prevented more far-ranging reforms. While the Irish PM Enda Kenny urged the other member states to 'give [Cameron] the tools for this fight' to win the referendum (Barker 2016), most eastern states were more unwilling to prevent a Brexit at any price. The conflict on the restriction of EU citizens' access to the British welfare system illustrates the argument. During the negotiations, the UK had to approach the so-called Visegrad Four States (Czech Republic, Hungary, Poland and Slovakia), which feared negative externalities from a policy change and potential sanctioning from their domestic voters. Although the UK secured a safeguard mechanism that allows states to limit the access of newly arriving EU citizens to in-work benefits for seven years, the outcome remains behind the original British demand, since it can neither be applied to EU migrants already living in Britain nor extended to a period of 13 years (Rankin 2016). In fact, the negotiation outcome is even closer to the five years that was initially proposed by the eastern States (ibid.). Another 
contested issue was the alteration of child benefits for EU citizens whose children do not reside in the same member state. Although the British government had already adjusted its demand from a complete stop to an indexation of child benefits before the February 2016 European Council summit, it had to make further concessions to the eastern member states despite strong support from some northern member states that also want to use the measure from 1 January 2020 onwards.

\section{Conclusion}

In this short contribution, we have examined the causal effect of the Brexit threat on the renegotiations of the British relationship with the EU. We have argued that the pledge to hold an in/out referendum did not yield far-ranging concessions to the UK. Thus, the two-level game was played with limited success by the British government. The reason for this failure is that the cost-benefit structure of the other member states was not affected in such a way as to overcome the logic of the joint decision trap. Although some British demands were fulfilled in the final agreement, the other member states were unwilling to pay any price to reduce the risk of the Brexit. In anticipation of the resistance, most British demands remained rather modest. While Cameron praised the outcome as a 'milestone on a journey' to reform the EU (Prime Minister's Office et al. 2016), we find the final deal to be a typical EU compromise intending to satisfy all sides. Furthermore, although the EU was willing to present the negotiations as a hard fight to make it easier for Cameron to persuade the British voters of remaining in the Union, the renegotiations did not calm the British Eurosceptics, with several Cabinet members, e.g., Justice Minister Michael Gove, and prominent Conservatives, e.g., London's Mayor Boris Johnson, campaigning in favour of a Brexit. We thus doubt that the strategy to use the EU level for domestic purposes has paid off in the end. Finally, while PM Cameron has declared that a vote of the British to leave the Union would be a final decision (Prime Minister's Office et al. 2016), we are sceptical whether the referendum will settle the European question in the UK. Instead it might rather be - in the words of an EU official - that 'whatever the outcome [of the referendum] will be, the day after, the [European] question will be there again' (EU official of the General Secretariat of the Council, Brussels, 5 October 2015).

\section{Acknowledgments}

The authors would like to thank the debate editors Graham Butler, Mads Dagnis Jensen and Holly Snaith; Hanno Degner, Kerstin Radtke and Sophia Schemel; European Research at the University of Copenhagen (EURECO), Anah Maskell and the anonymous reviewers for helpful comments and suggestions, as well as the interview partners. 


\section{Disclosure statement}

No potential conflict of interest was reported by the authors.

\section{Notes on contributors}

Daniela Annette Kroll is a research assistant and PhD candidate, University of Konstanz, Germany.

Dirk Leuffen is professor of political science and international politics, University of Konstanz, Germany.

\section{References}

Barker, A. (2016) 'Cameron frustrated as "British question" EU talks roll on', The Financial Times, 19 February, available at http://www.ft.com/intl/cms/s/0/0f600c80-d6b911e5-969e-9d801cf5e15b.html\#axzz434WC9P8v (accessed March 2016).

Booth, S., Ruparel, R. and Scarpetta, V. (2015) 'EU reform heat-map: where do EU countries stand on the UK's EU reform demands?', Briefing 11/2015, Brussels: Open Europe.

Brattberg, E. (2014) 'Sweden', in A. Möller and T. Oliver (eds), 'The United Kingdom and the European Union: what would a "Brexit" mean for the EU and other states around the world?', DGAPanalyse, Berlin: Deutsche Gesellschaft für Auswärtige Politik e.V., pp. 77-8.

Buchsteiner, J. (2015) 'Die geheimen Wünsche des David Cameron', F.A.Z., 11 November, available at http://www.msn.com/de-de/nachrichten/politik/diegeheimen-w\%C3\%BCnsche-des-david-cameron/ar-CCcJ9e (accessed January 2016).

Bundeskanzleramt (2015) 'Pressekonferenz von Bundeskanzlerin Merkel und dem Premierminister des Vereinigten Königreiches Großbritannien und Nordirland, Cameron', available at http://www.bundesregierung.de/Content/DE/Mitschrift/Presse konferenzen/2015/05/2015-05-29-pk-merkel-cameron.html (accessed November 2015).

Butler, G., Jensen, M.D. and Snaith, H. (2016) "'Slow change may pull us apart": debating a British Exit from the European Union', Journal of European Public Policy.

Cameron, D. (2015) 'Prime minister: conference speech 2015', available at http://press. conservatives.com/post/130746609060/prime-minister-conference-speech-2015 (accessed November 2015).

Department of the Taoiseach (2015) 'Address by An Taoiseach, Mr Enda Kenny TD to the Confederation of British Industry Annual Conference 9 November Grosvenor House Hotel, London, "Securing our global future in a changing world"', available at http://www.taoiseach.gov.ie/eng/News/Taoiseach's Speeches/Address by An Taoiseach Mr Enda Kenny TD to the Confederation of British Industry Annual Conference 9 November Grosvenor House Hotel London Securing our global future in a changing world .html (accessed March 2016).

Dobbins, M., Schneider, G. and Zimmer, C. (2005) 'The contested council: conflict dimensions of an intergovernmental EU institution', Political Studies 53(2): 403-22.

European Council (2016) 'Letter by President Donald Tusk to the Members of the European Council on his proposal for a new settlement for the United Kingdom within the European Union', available at http://www.consilium.europa.eu/en/ 
press/press-releases/2016/02/02-letter-tusk-proposal-new-settlement-uk/ (accessed March 2016).

Evans, P.B., Jacobson, H.K. and Putnam, R. (eds) (1993) Double-Edged Diplomacy. International Bargaining and Domestic Politics, Berkeley and Los Angeles, CA: University of California Press.

Fearon, J.D. (1994) 'Domestic political audiences and the escalation of international disputes', The American Political Science Review 88(3): 577-92.

Holzinger, K. and Schimmelfennig, F. (2012) 'Differentiated integration in the European Union: many concepts, sparse theory, few data', Journal of European Public Policy 19 (2): 292-305.

Jensen, C.B. and Slapin, J.B. (2012) 'Institutional hokey-pokey: the politics of multispeed integration in the European Union', Journal of European Public Policy 19(6): 779-95.

Jensen, M.D. and Snaith, H. (2016) 'When politics prevails: the political economy of a Brexit', Journal of European Public Policy

Korteweg, R. (2014) 'The Netherlands', in A. Möller and T. Oliver (eds), 'The United Kingdom and the European Union: what would a 'Brexit' mean for the EU and other states around the world?', DGAPanalyse, Berlin: Deutsche Gesellschaft für Auswärtige Politik e.V., pp. 99-101.

Kroll, D.A. and Leuffen, D. (2015) 'Enhanced cooperation in practice. An analysis of differentiated integration in EU secondary law', Journal of European Public Policy 22(3): 353-73.

Leuffen, D., Schimmelfennig, F. and Rittberger, B. (2015) 'The European Union as a system of differentiated integration: interdependence, politicization and differentiation', Journal of European Public Policy 22(6): 764-82.

Oliver, T. (2016) 'European and International views of Brexit', Journal of European Public Policy

Prime Minister's Office, 10 Downing Street and The Rt Hon David Cameron MP (2015) 'Prime minister's speech on Europe', available at https://www.gov.uk/government/ speeches/prime-ministers-speech-on-europe (accessed November 2015).

Prime Minister's Office, 10 Downing Street and The RT Hon David Cameron MP (2016) 'PM statement following European Council meeting: 19 February 2016', available at https://www.gov.uk/government/speeches/pms-statement-following-europeancouncil-meeting-19-february-2016 (accessed March 2016).

Putnam, R.D. (1988) 'Diplomacy and domestic politics: the logic of two-level games', International Organization 42(3): 427-60.

Rankin, J. (2016) 'David Cameron's EU deal: what he wanted and what he got', The Guardian, 19 February, available at http://www.theguardian.com/world/2016/feb/ 19/camerons-eu-deal-what-he-wanted-and-what-he-got (accessed March 2016).

Scharpf, F.W. (1988) 'The joint decision trap. Lessons from German federalism and European integration', Public Administration 66(3): 239-78.

Schelling, T.C. (1963) The Strategy of Conflict, New York: Oxford University Press.

Stubb, A.C. (1996) 'A categorization of differentiated integration', Journal of Common Market Studies 34(2): 283-95.

Thomson, R. (2011) Resolving Controversy in the European Union. Legislative DecisionMaking Before and After Enlargement, Cambridge: Cambridge University Press.

Traynor, I. (2015) 'So what does Europe really think about the Brexit debate? As David Cameron finally promises to put his shopping list of demands on the table, how will the UK's European partners react?', The Guardian, 18 October, available at http:// www.theguardian.com/global/2015/oct/18/brexit-what-european-leaders-thinkmerkel-hollande (accessed October 2015). 
Tsebelis, G. (2002) Veto Players, Princeton, NJ: Princeton University Press.

van Aken, W. (2012) 'Voting in the Council of the European Union. Contested decisionmaking in the EU Council of Ministers (1995-2010)', Report 2, Stockholm: SIEPS.

Zalan, E. (2016) 'Cameron-EU deal is "good enough"', EUObserver, available at https:// euobserver.com/political/132108 (accessed March 2016).

Zuleeg, F. (2014) 'The view from Brussels', in A. Möller and T. Oliver (eds), 'The United Kingdom and the European Union: what would a 'Brexit' mean for the EU and other states around the world?', DGAPanalyse, Berlin: Deutsche Gesellschaft für Auswärtige Politik e.V., pp. 59-62. 